\title{
Preface
}

Despite the intervening centuries of discussions, firstly in Philosophy, then in Psychology and Pedagogy, and recently even in Computer Science, the search for excellent approaches regarding how to effectively teach and learn is still a challenge of our times. This became a very relevant issue during the last decades, parallel with the development of Information and Communication Technologies applied to education and learning and, particularly, with the new paradigms implied in online learning technologies and methodologies.

The continuous advances in technology cause innovation-acceptation-consolidation-obsolescence flows regarding the knowledge and technology management strategies, both ad-hoc and planned, of the corporations and also, in a different scale, of the individuals. Teaching and learning processes are not obviously unaware of this situation. Since the rising of the Internet and the eLearning revolution and, even before that, since the early origins of distance learning, there were many significant changes regarding technology, interaction, and communication models, new supports for learning contents, and even the rupture of time/space frontiers to facilitate teaching and learning activities.

The Information and Communication Technologies (ICT) irruption as educational tool means both conceptual and methodological turning point in the way that institutions, educational ones or not, face training processes and learning management, especially in regard to the distance education concept, which evolves, in a more or less significant way, when it adopts Internet as media; this way the eLearning concept is born (García-Peñalvo, 2005, 2008).

However, from the first eLearning experiences, too much settled on the concept of platform or Learning Management System (LMS), to the present there have been significant changes, again in both technological and methodological levels, in which ones, among others, it is important to underline the social media influences in the daily habits of users. This shift towards social learning is evident when at the end of 2012 more that $50 \%$ of Internet users belonged to any social network. This fact is presented in various studies and reports throughout the world (for example, in Spain in 2011 the 52\% of the Internet users belonged to a social network, the $95 \%$ of these were in Facebook, in comparison with the 53\% European Union ratio (Gimeno, 2012); 67\% of EEUU Internet users belong to a social network, which coincides with the percentage of Facebook users (Duggan \& Brenner, 2013); 51\% of Internet users are active users of Facebook, 25\% of Google+ and 21\% of YouTube and Twitter (Petersen, 2013)).

This way, it is shown an increased demand of learning personalization, a complete connectivity with other peers, a unlimited access to resources and information sources, a plenty flexibility in the way,

place and time they access, and a natural and necessary coexistence of the formal and informal learning flows (García-Peñalvo, Colomo-Palacios, \& Lytras, 2012). 
The "traditional" eLearning platforms have a high penetration and they are very consolidated, 100\% of the Universities has one LMS at least and $79.5 \%$ of the big corporations uses this platforms in their eLearning training activities (Wexler et al., 2007). However these LMS are sharing their stage with a wide range of tools, services and environments Web 2.0 oriented (O'Reilly, 2007), which ones allow setting up learning ecosystems (García-Holgado \& García-Peñalvo, 2013) that are congruent with Virtual Learning Environment (VLE) notion. Unlike the concept of LMS, VLE involve a wider spectrum of possibilities from which also include the LMS (García-Peñalvo \& García Carrasco, 2002), but with an approach that is closer to the Personal Learning Environment (PLE) concept (Attwell, 2007).

This way, LMS need to evolve and open themselves to support this rich fan of possibilities demanded by the users in open and distributed contexts (Casany-Guerrero, Alier-Forment, Conde-González, \& García-Peñalvo, 2009; Casquero, 2013; García-Peñalvo, Conde, Alier, \& Casany, 2011). These users are students in a digital era, which requires them to develop a range of competencies and skills to prepare them for a life in constant technological evolution (Hoobs, 2011), among which we should highlight the skills to listen, seek diverse nature information in complex technological ecosystems, constantly interacting with other peers, manage their digital identity or actively produce digital contents, among others.

Even with the exciting revolution brought by the eLearning methods, technologies, and strategies, the real fact is that learning results were not as good as expected. We do not learn significantly better or more than before despite the innovations in terms of skills and competences effectively acquired by learners. That is the real problem.

Which is the real solution? Maybe we made technology, interaction models, and strategies evolve without upgrading and fitting the human factor (teachers and learners) to these new solutions. Researchers still need to develop a new model for online training regarding human interaction and, above all, teaching roles involved in these learning processes.

In the last 10 years, different methodologies and models regarding online tutoring have been theoretically developed and implemented. However, online tutoring and strategies are very different from one context to another, and a suite of didactical patterns is still needed in order to plan online tutoring strategies.

In this book, we want to collect new methodologies and approaches, successful cases, and pedagogical patterns for online tutoring and mentoring initiatives in formal, non-formal, or informal learning contexts, based upon Ancient Greek paideía models of learning communities and teaching (mentoring) roles (Seoane-Pardo \& García-Peñalvo, 2007; Seoane-Pardo \& García-Peñalvo, 2008a, 2008b), which are so present now in the current 2.0 collaborative and social perspectives.

\section{ORGANIZATION OF THE BOOK}

The main goal of this book will be to demonstrate, throughout the exposure of successful cases in online education and training, how these tutoring and mentoring cases, especially regarding an eLearning 2.0 (or 3.0) approach, will be revealed as a powerful solution for developing online learning strategies for different organizations and contexts, always taking into account the human power or human effects that other silver bullets or fashionable trends, such as MOOCs (Zapata-Ros, 2013), are usually forgetting, when the human factor is crucial, and particularly teaching/tutoring roles, for ensuring the development of quality and excellent learning activities. The didactical patterns extracted from these successful cases may be the basis for a more powerful and efficient new generation of technology-based learning solutions. 
In fact, the book is organized into fifteen chapters. A brief description of each of the chapters follows: In Chapter $1 \mathrm{Lal}$ presents an attempt to understand the use of Learning Analytics that advocates for analysis of the courses delivered in LMS in order to know better the learning process in terms of student engagement, pedagogy, content and assessment. This way, the educational institutes will be able to utilize the intelligence revealed by learning analytics processes and communicate them to those involved in strategic institutional planning.

Díaz San Millán and Gutiérrez Priego explore the Gamification and Game-Based Learning concepts in order to highlight their influence on the transmission of knowledge and development of competencies and skills in the Society of Knowledge in Chapter 2 and they discuss the MOOC phenomenon in Chapter 3.

Chapter 4 explores eLearning use in developing countries, using Croatia as an example. In this chapter the authors want to identify perspectives and obstacles defined by users and non-users of eLearning. Four in-depth interviews are presented to get a more extensive picture of educational institutions that use eLearning in the teaching process. This chapter has been authored by Zoroja, Skok and Bach.

In Chapter 5, Pandolfini presents a case study of a training course involving Italian early-secondary schoolteachers, which focuses on online tutors' activities and roles. The aim is to analyze the roles played by tutors in the 2.0 learning environment, exploring when, how and why they used synchronous and asynchronous communicative tools and educational resources available on the e-learning platform, as well the kind of support they provided to learners and the relationship they established with them during the training path.

Vlachopoulos and Cowan deal in Chapter 6 with the e-moderation issues. These authors emphasize that one of the success factors in online courses is the design of the interactions between learners and learners, and of learners with tutors. Although there is a great body of literature that deals with the role of the online tutor or e-moderator in formal learning contexts, little has been published about the principles on which the development and exercise of the e-moderator's facilitative skills in nurturing the development of higher level abilities should be founded. They have the aim of reconceptualizing some of the key facilitative skills derived from the humanistic principles of human relationships set out five decades ago by Carl Rogers, and their use and evaluation subsequently within educational practice. In so doing, the authors are conscious of presenting a controversial view, and of advocating practice contentiously at variance with some present developments in this field.

Chapter 7, by Tan and Loughlin, explores the blurred boundaries between formal and informal and considers how blogs hosted within a virtual learning environment or VLE can serve as informal online learning environments. The use of blogs for reflection is a widespread and frequently occurring incidence in higher education. Evidence and research regarding the benefits and potential to enhance student learning by using such a tool reflectively is widely reported. There are various iterations of the set-up of such a method with the tool taking on a number of forms both internally, hosted within the VLE, and externally located. In the practice of externally located blogs, the responsibility for establishing, setting up and maintaining their own blogs is devolved to the students. This is commonly termed an informal learning environment. The practice of establishing blogs within a VLE, in contrast, has frequently been cited as a formal means of interaction and engagement. As if to highlight the use of blogs in formal practice, they are now an increasingly common form of assessment.

In Chapter 8, entitled "Three Degrees of Separation: Strategies for Mentoring Distanced Transnational Learners," Starr-Glass considers changes in the underlying dynamics of mentoring when it moves to a distanced experience. Specifically, he examines the mentoring program of an American college with students in the Czech Republic, where distanced mentoring supports the completion of an undergraduate 
dissertation. The chapter reviews the various "distances" encountered and their impact on the mentoring relationship. The main thrust of the chapter is to consider changes in the underlying dynamics of mentoring when it moves to a distanced experience. The effectiveness of mentoring depends on recognizing, adjusting, and strengthening these dynamics. Based on this theoretical framework, and the author's extensive distance mentoring practice, actionable strategies are presented for strengthening relational bonds and improving e-mentoring effectiveness.

Chapter 9, by Pange, is devoted to outline the use of the Socratic Teaching Method (STM) in eLearning 2.0 practice. The chapter gives the author's perspective regarding some very interesting issues, such as: a) the range of subjects that could be taught using the STM teaching practice, b) the educators' additional skills needed in order to apply STM to their online teaching, and c) whether the STM is an adequate learning approach in order to assure learners' mastery of a subject.

Shen and Chen explore in Chapter 10 the online instructors' distance dissertation mentorship through social presence. Eight dissertation chairs have been invited to answer in-depth interview questions in the presented case study. The theories and definitions of social presence, the effectiveness of social presence in online courses, and the strategies to improve social presence in online settings have been reviewed. Major findings of this study revealed the critical role of social presence in dissertation mentoring, successful strategies to improve social presence in online dissertation courses, teachers' limited use of social media, emoticons, and University Mobile 3.0, the need for synchronous virtual interaction in online dissertation classes, and teachers' challenges of online dissertation mentorship.

Chapter 11 discusses new e-learning technologies considering their pedagogical and effective implications. The most frequently asked and investigated question in education is the way that effective use of technology can respond to accelerating global competition for learning experiences, remove situational barriers and be more cost effective. As eLearning has become more pervasive, however, expressions of uncertainty, concern, and scepticism have also emerged. The growing lists of concerns include commercialization of teaching; lack of face-time between students and teachers; techno-centric models prioritized over face-to-face culture; devaluation of oral discourse/discussion practices; centralization of decision-making and service provision; concerns that complex and deep learning cannot be satisfactorily achieved without real-time classroom experience; increased technological and pedagogical uniformity; surveillance options that violate privacy policies; recontextualization of established cultural practices, such as education as a cultural discourse; and concern about the growing digital divide and downloading of costs to students. Tools and Technologies on the other hand have a potential for catering needs for all levels of education irrespective of time and place. This chapter is authored by Parlakk1liç.

O'Brien and Hamburg present in Chapter 12 a discussion of informal and formal mentoring applied within the public domain. They examine mentoring as an informal learning tool and the shortcomings of the methods currently used in companies. They also examine the use of mentoring in problem-based learning and make recommendations for the use of both Web 2.0 and social media tools for mentoring in companies.

Chapter 13, by Perry, concerns a yearlong, United States federally funded evaluation of Educate Online, an online, at home, 1:1 tutoring program aimed at improving reading performance for middle school students who are below grade level. Participating students receive after-school instruction from teachers in real-time over Voice over Internet Protocol (VoIP) connections. The author discusses study findings, the methodological challenges of conducting research on online tutoring, the multiple perspectives for understanding the effectiveness of a tutoring program, and areas for additional research. He also 
examines a key aspect of the evaluation, a delayed treatment control group design study to determine the effect that involvement in the tutoring program has upon student academic achievement in reading.

McCarthy, in Chapter 14, reports on the use of Facebook as the host site for a collaborative international animation forum between student cohorts from the University of South Australia in Australia, Penn State University in the United States of America, and Nanyang Technological University in Singapore. The findings of the study are discussed in light of the growing use of social media to support mentoring, learning and teaching in tertiary education, particularly in the fields of design and digital media.

In the last chapter Seoane-Pardo and García-Peñalvo summarize the experience collected after years of researching and experiencing on teaching and learning online in the form of an eLearning patternarchitecture. In this architecture, based upon the leading role of the human factor (according to the vision of the eLearning by GRIAL Group), the whole processes occurring within any training activity will be represented, from the institutional planning to the evaluation of the whole process, technological decisions, teaching activity and interaction with students, and so forth.

Francisco José García-Peñalvo

University of Salamanca, Spain

Antonio Miguel Seoane-Pardo

University of Salamanca, Spain

\section{ACKNOWLEDGMENT}

This work is partially supported by the Regional Council of Education of Junta de Castilla y León through the project GR47.

\section{REFERENCES}

Attwell, G. (2007). The personal learning environments - The future of eLearning?. eLearning Papers, 2(1).

Casany-Guerrero, M. J., Alier-Forment, M., Conde-González, M. Á., \& García-Peñalvo, F. J. (2009). SOA initiatives for eLearning. A Moodle case 23rd International Conference on Advanced Information Networking and Applications, AINA 2009, Workshops Proceedings. The International Symposium on Mining and Web (MAW 2009) (pp. 750-755). Los Alamitos, CA: IEEE Computer Society.

Casquero, O. (2013). PLE: Una perspectiva tecnológica. In L. Castañeda, \& J. Adell (Eds.), Entornos personalizados de aprendizaje: Claves para el ecosistema educativo en red (pp. 71-84). Alicante, Spain: Marfil.

Duggan, M., \& Brenner, J. (2013). The demographics of social media users - 2012. Pew Research Center's Internet \& American Life Project.

García-Holgado, A., \& García-Peñalvo, F. J. (2013). The evolution of the technological ecosystems: An architectural proposal to enhancing learning processes. Paper presented at the TEEM Conference'13, Salamanca, Spain. 
García-Peñalvo, F. J. (2005). Estado actual de los sistemas e-learning. Teoría de la Educación. Educación y Cultura en la Sociedad de la Información, 6(2).

García-Peñalvo, F. J. (2008). Advances in e-learning: Experiences and methodologies. Hershey, PA: Information Science Reference. doi:10.4018/978-1-59904-756-0

García-Peñalvo, F. J., Colomo-Palacios, R., \& Lytras, M. D. (2012). Informal learning in work environments: training with the Social Web in the workplace. Behaviour \& Information Technology, 31(8), 753-755. doi:10.1080/0144929X.2012.661548

García-Peñalvo, F. J., Conde, M. A., Alier, M., \& Casany, M. J. (2011). Opening learning management systems to personal learning environments. Journal of Universal Computer Science, 17(9), 1222-1240.

García-Peñalvo, F. J., \& García Carrasco, J. (2002). Los espacios virtuales educativos en el ámbito de Internet: Un refuerzo a la formación tradicional. Teoría de la Educación. Educación y Cultura en la Sociedad de la Información, 3.

Gimeno, M. (2012). eEspaña 2012. Informe anual 2012 sobre el desarrollo de la sociedad de la información en España. Madrid, Spain: Fundación Orange.

Hoobs, R. (2011). Digital and media literacy: Connecting culture and classroom. Thousand Oaks, CA: Corwin Press.

O'Reilly, T. (2007). What is Web 2.0: Design patterns and business models for the next generation of software. Communications \& Strategies, 1(65), 17-37.

Petersen, B. (2013). Social platforms GWI.8 update: Decline of local social media platforms. Retrieved from http://globalwebindex.net/thinking/social-platforms-gwi-8-update-decline-of-local-social-mediaplatforms/

Seoane-Pardo, A. M., \& García-Peñalvo, F. J. (2007). Los orígenes del tutor: Fundamentos filosóficos y epistemológicos de la monitorización para su aplicación a contextos de e-learning. Teoría de la Educación: Educación y Cultura en la Sociedad de la Información, 8(2), 9-30.

Seoane-Pardo, A. M., \& García-Peñalvo, F. J. (2008a). Online Tutoring and Mentoring. In G. D. Putnik, \& M. M. Cunha (Eds.), Encyclopedia of networked and virtual organizations (Vol. II, pp. 1120-1127). Hershey, PA: Information Science Reference. doi:10.4018/978-1-59904-885-7.ch147

Seoane-Pardo, A. M., \& García-Peñalvo, F. J. (2008b). Philosophical and epistemological basis for building a quality online training methodology. In F. J. García-Peñalvo (Ed.), Advances in e-learning: Experiences and methodologies (pp. 46-60). Hershey, PA: Information Science Reference. doi:10.4018/9781-59904-756-0.ch003

Wexler, S., Dublin, L., Grey, N., Jagannathan, S., Karrer, T., Martinez, M., et al. (2007). Learning management systems. The good, the bad, the ugly, ..., \& the truth Guild Research 360 Degree Report. Santa Rosa, CA: The eLearning Guild. 
